\title{
How urgent are cases brought to the emergency department by ambulance?
}

\author{
Acil servise ambulans ile getirilen hastalar ne kadar acil? \\ Melih Yuksel ${ }^{1}$, Caner Saglam², Muharrem Çakmak ${ }^{3}$, Erkan Baysal ${ }^{4}$, Aynur Altunbay $^{5}$, Sultan Baran $^{5}$
}

\begin{abstract}
Objective: Emergency departments are the first places to which patients present with unexpected or unforeseen health problems. The purpose of this study was to assess the urgency of cases brought by ambulance to the Hospital on the basis of a three-level triage system.
\end{abstract}

Methods: This study was performed between 01.06.2013 and 31.09.2013 at the Diyarbakır Education and Research Hospital. Our emergency service unit is a third degree service for all adult patient groups and all child trauma types. Triage of patients brought to the emergency department by ambulance was performed by emergency medicine specialists. Patients' vital findings, identity data and triage categories were assessed.

Results: 712 patients were included, 382 (53.7\%) male and $330(46.3 \%)$ female, with a mean age of 45 . In this study, $619(86.9 \%)$ patients were transferred from the scene and 93 (13.1) between hospitals, 483 (67.8\%) patients were brought by emergency medicine technician (EMT) teams, 107 (15\%) by physician-led teams, 107 (15) by paramedic teams and $15(2.1 \%)$ by other teams, 442 $(62.1 \%)$ patients were assessed as yellow, $141(19.8 \%)$ as green and $129(19.1 \%)$ as red zone. Five hundred eighty $(81.5 \%)$ patients were discharged and 115 (15.9\%) were hospitalized.

Conclusion: Emergency health services are clearly developing rapidly in Turkey. In order for pre-hospital emergency health services not to be abused, we think that these services should be up to the standards of those in developed countries and that public awareness needs to be increased, particularly with regard to triage. J Clin Exp Invest 2015; 6 (2): 126-129

Key words: Emergency medicine, triage, ambulance

\section{ÖZET}

Amaç: Acil servisler, beklenmeyen veya öngörülemeyen sağlık sorunlarının çözümü için başvurulan hastanelerin ilk bakı yerlerdir. Bu çalışmanın amacı; Hastane Acil servisine ambulans ile getirilen hastaların üç basamaklı triyaj sistemine göre aciliyet durumunu değerlendirmektir.

Yöntemler: Bu çalışma 01.06.2013-31.09.2013 tarihleri arasında Diyarbakır Eğitim ve Araştırma Hastanesindeki acil serviste yapılmıştır. Acil servisimiz, Erişkin tüm hasta grupları ve tüm çocuk travmalarına bakılan 3. basamak bir acil servistir. Acil servise ambulans ile getirilen hastaların triyajı acil tıp uzmanlarınca yapıldı. Hastaların vital bulguları, kimlik bilgileri ve triyaj kategorileri değerlendirildi.

Bulgular: Çalışmaya 712 hasta alındı. Hastaların ortalama yaşı 45 olup 382' si $(\% 53,7)$ erkek, 330' u ise (\%46,3) kadındı. Bu çalışmada, hastaların 619'u $(\% 86,9)$ olay yerinden, 93' ü $(\% 13,1)$ ise hastaneler arası sevk ile getirildi. Hastaların 483'ü $(\% 67,8)$ acil tıp teknisyenli (ATT), 107 'si (\%15) doktorlu, 107' si (\%15) paramedikli ekip ve 15 'i $(\% 2,1)$ ise diğer ekipler aracılığıyla getirildi. Hastaların 442'si $(\% 62,1)$ sarı, 141'i $(\% 19,8)$ yeşil ve 129'u $(\% 19,1)$ kırmızı alan hastası olarak değerlendirildi. Hastaların 580'i $(\% 81,5)$ taburcu olurken, 115 'i $(\% 15,9)$ ise hastaneye yatırıldı.

Sonuç: Ülkemizde acil sağlık hizmetlerinin hızlı bir şekilde verilmekte olduğu aşikardır. Hastane öncesi acil sağlık hizmetlerinin suiistimal edilmemesi için, bu hizmetlerin gelişmiş ülkeler standartlarında olması gerektiği ve triyaj uygulaması hakkında eğitim çalışmaları başta olmak üzere toplumun bilgilendirilmesinin faydalı olacağını düşünmekteyiz.

Anahtar kelimeler: Acil tıp, triyaj, ambulans

${ }^{1}$ Balıkesir University, School of Medicine, Department of Emergency Medicine, Balıkesir, Turkey

${ }^{2}$ Gazi Yasargil Training and Research Hospital, Department of Emergency Medicine, Diyarbakır, Turkey

${ }^{3}$ Gazi Yasargil Training and Research Hospital, Department of Thoracic Surgery, Diyarbakır, Turkey

${ }^{4}$ Gazi Yasargil Training and Research Hospital, Department of Cardiology, Diyarbakır, Turkey

${ }^{5}$ Gazi Yasargil Training and Research Hospital, Department of Emergency Medicine, Diyarbakır, Turkey

Correspondence: Melih Yuksel,

Balıkkesir University, School of Medicine, Department of Emergency Medicine, Balıkesir, Turkey Email: melihdr@gmail.com

Received: 06.05.2015, Accepted: 09.06.2015

Copyright @ JCEI / Journal of Clinical and Experimental Investigations 2015, All rights reserved 


\section{INTRODUCTION}

Emergency departments are the first places to which patients present with unexpected or unforeseen health problems. This is one of the main distinguishing features between emergency departments and other hospital sections. Providing effective and reliable treatment is one of the most important tasks of emergency departments. In order to provide this effective and reliable treatment, patients have to be classified on the basis of their clinical conditions. The process of classifying and prioritizing patients in this way is known as triage [1]. Globally widely used triage systems include the Manchester Triage System, the Australian Triage System and the Canadian Triage and Acuity System. These all consist of five levels. In contrast, the "Rules and Principles Concerning the Application of Emergency Department Services in Health Facilities with Beds" published by the Turkish Ministry of Health on 16.10.2006 involves three color levels [2].

The basic aim of pre-hospital emergency health and ambulance services is to transport the patient from the scene to the emergency department in an appropriate time and conditions and also to initiate effective treatment and procedures without loss of time.

The purpose of this study was to assess the urgency of cases brought by ambulance to the Diyarbakır Education and Research Hospital on the basis of a three-level triage system.

\section{METHODS}

This study was performed between 01.06.2013 and 31.09.2013 at the emergency department at the Diyarbakır Education and Research Hospital Üçkuyular campus. Some 110,000 patients present to our hospital's emergency department every year. This is a tertiary emergency department covering all adult patient groups and all pediatric traumas. Patient care is primarily given by emergency medicine specialists. Patients brought in by emergency department ambulance were assessed in the triage zone by emergency medicine specialists. Patients' vital findings, identity data, symptoms for which ambulances were summoned and triage categories were evaluated. The patient's latest status was then recorded. Patients brought in with arrest were excluded from the study. The patients were classified as yellow, red and green according to the threelevel triage system. Ethical committee approval was granted for the study.

\section{Statistical analysis}

All data were transferred onto SPSS for Windows Ver. 13.0, (SPSS Inc., IL, USA) software for analysis. One-way analysis of variance (ANOVA) was used for the analysis of parametric variables, and Pearson's chi square test and Wilcoxon's test for non-parametric (qualitative) variables. Quantitative data were recorded as number of observations and percentages (\%), and qualitative data as mean \pm standard deviation (SD) or median (minimum maximum). A $p$ value $<0.05$ at a $95 \%$ confidence interval was regarded as significant.

\section{RESULTS}

Seven hundred twelve patients were enrolled, 382 $(53.7 \%)$ male and $330(46.3 \%)$ female, with a mean age of 45 . Six hundred nineteen $(86.9 \%)$ patients were transferred from the scene and 93 (13.1) between hospitals. Four hundred eighty three $(67.8 \%)$ patients were brought in by emergency medicine technician (EMT) teams, 107 (15\%) by physicianled teams, 107 (15) by paramedic teams and 15 $(2.1 \%)$ by other (health technician, nurses) teams. Four hundred forty-two (62.1\%) were assessed as yellow, 141 (19.8\%) as green and 129 (19.1\%) as red zone. Five hundred eighty $(81.5 \%)$ patients were discharged and 115 (15.9\%) were hospitalized (Table 1).

Of the 483 patients brought in by EMT teams, $311(64.4 \%)$ were yellow zone, $73(15.1 \%)$ red zone and $99(20.5 \%)$ green zone patients. Of the 107 patients brought in by physician-led teams, 57 (53.3\%) were yellow zone, $31(29 \%)$ red zone and $19(17.7 \%)$ green zone. Of the 107 patients brought in by paramedic teams, $67(62.6 \%)$ were yellow zone, $19(17.8 \%)$ red zone and 21 (19.6\%) green zone. The hospitalization rate in the 129 red zone patients brought in by teams was $72.8 \%$, compared to $7.2 \%$ in yellow zone cases. No green zone patients were hospitalized. A statistically significant difference among patient groups has been observed $(p<0.05)$. (Table 2).

Two hundred patients were aged 65 or more, and cardiovascular system findings were determined in $64(32 \%)$ of these. Five hundred twelve patients were aged below 65 , and $160(31.8 \%)$ of these were trauma patients. A statistically meaningful difference in the symptoms of patients above 65 and below 65 has been observed $(p<0.05)$ (Table $3)$. 
Table 1. Demographic and clinical data of patients

\begin{tabular}{lc}
\hline Variable & $\mathbf{n}(\%)$ \\
\hline Age (Median, IQR) & $45(40)$ \\
Gender & \\
Male & $382(53.7)$ \\
Female & $330(46.3)$ \\
Triage Categories & \\
Red & $129(19.1)$ \\
Yellow & $442(62.1)$ \\
Green & $141(19.8)$ \\
Last status of patients & \\
Discharge & $580(81.5)$ \\
Hospitalization & $113(15.9)$ \\
Dispatch & $13(1.8)$ \\
Other & $6(0.8)$ \\
Mission of ambulance team & \\
Physician & $107(15)$ \\
Paramedic & $107(15)$ \\
EMT & $483(67.8)$ \\
Other & $15(2.1)$ \\
Patient location & $619(86.9)$ \\
Event location & $93.1)$ \\
\hline Hospital & \\
\hline
\end{tabular}

EMT: Emergency Medicine Technician, IQR: Interquartile range

\section{DISCUSSION}

Until the mid-1980s, ambulance services in Turkey were provided by municipalities, with insufficient personnel and equipment and no standardization. In 1986, a service known as the '007 Rapid Emergency Service' began being provided by various greater municipalities with Ministry of Health support. On 14 March, 1994, the Rapid Emergency Service was attached to the Ministry of Health and the name was changed to the '112 Emergency Assistance and Rescue Service.' This is currently in operation across the country with thousands of vehicles (such as land, sea and air ambulances) and personnel.

Two hundred $(28 \%)$ of the 712 cases in this study were aged over 65 . In a study performed by Türkdoğan et al., the annual proportion of patients who are above 65 has been found to be $12.7 \%$ [3]. In a study of 6782 presentations by Nur et al., $22.2 \%$ of cases were aged 65 or over [4]. Several studies have shown that elderly patients have greater
Table 2. The hospitalization rates of patients arriving through ambulance according to the triage category

\begin{tabular}{lcccr}
\hline Team & $\begin{array}{c}\text { Red } \\
\mathbf{n}(\%)\end{array}$ & $\begin{array}{c}\text { Yellow } \\
\mathbf{n}(\%)\end{array}$ & $\begin{array}{c}\text { Green } \\
\mathbf{n}(\%)\end{array}$ & \\
\cline { 1 - 4 } EMT & $73(73.9)$ & $311(6.7)$ & $99(20.4)$ & \\
Physician & $31(67.7)$ & $57(5.2)$ & $19(17.5)$ & $\mathbf{p}<0.05^{*}$ \\
Paramedic & $19(73.6)$ & $67(8.9)$ & $21(19.6)$ & \\
Other & $6(83.3)$ & $7(28)$ & $2(13.3)$ & \\
\cline { 1 - 4 } Total & $129(72.8)$ & $442(7.2)$ & $141(19.8)$ & \\
\hline
\end{tabular}

EMT: Emergency Medicine Technician, ${ }^{*}$ chi squared $\left(x^{2}\right)$ test

Table 3. Patient symptoms according to age groups

\begin{tabular}{|c|c|c|c|}
\hline Symptom & $\begin{array}{c}\geq 65 \text { years } \\
n(\%)\end{array}$ & $\begin{array}{c}<65 \text { years } \\
\text { n (\%) }\end{array}$ & \\
\hline CVS & $64(32)$ & $62(12.1)$ & \\
\hline Neurology & $42(21)$ & 63 (12.3) & \\
\hline Respiratory & $24(12)$ & $16(3.1)$ & \\
\hline Trauma & $22(11)$ & $160(31.3)$ & $p<0.05^{*}$ \\
\hline Gis & $16(8)$ & $43(8.4)$ & \\
\hline İnfection & $11(5.5)$ & $46(9)$ & \\
\hline Other & $21(10.5)$ & $122(23.8)$ & \\
\hline Total & $200(28.1)$ & 712 (71.9) & \\
\hline
\end{tabular}

CVS: Cardiovascular system, Gis: Gastrointestinal system, ${ }^{*}$ Chi square $\left(X^{2}\right)$ test

ambulance requirements than the normal population [5-10]. Since only cases arriving by ambulance were investigated in this study it was not possible to assess rates of ambulance use by elderly subjects among all cases presenting to the emergency department.

The inter-hospital transfer group represented $13.1 \%$ of all arrivals by ambulance in this study. In contrast, the patient group involving transportation from emergency departments and clinics constituted $83.6 \%$ of all requests for ambulances in a study from Turkey by Yıldız et al. in 2004 [11]. We attribute the difference between the two studies to an increase in ambulance services in Turkey in the intervening period, to increased public awareness of existing services and to greater demand for them.

The levels of physician-led teams in ambulance services other than for interhospital transport vary in studies from the early 2000 s between $49.6 \%$ and $88.9 \%$. The level in our study was only $15 \%$, however [11-13]. We attribute this difference to increas- 
ing emergency service requirements and to the rising numbers of trained paramedical and emergency service technicians.

A significant greater number of cases assessed as red zone were brought to the emergency by physician-led teams in this study compared to other teams. We attribute this to the experience of the command control center directing ambulance teams in referring physician-led teams to critical patients. We attribute this to the experience of the command control center directing ambulance teams in referring physician-led teams to critical patients.

The fact that $19.8 \%$ of cases brought to the emergency department by the 112 system were capable of treatment on an outpatient basis is striking. There was no significant difference between physician-led and other teams in terms of bringing green zone patients to hospital. It is not cost-effective for green zone patients to use the ambulance service for transportation to the emergency department. There may be two factors responsible for this, patients being unable to decide on whether their cases are urgent or not, or pressure from relatives on the hospital transportation team. We think that physician-led teams transporting as many green zone patients as other teams in this study, despite the clinical decision-making process, is due to pressure from patients and relatives concerning hospital attendance. We think that greater research is needed into ambulance services provided for green zone patients.

Discharge level among patients arriving at hospital by ambulance was one of the criteria for measuring inappropriate ambulance use in a meta-analysis by Snooks et al. [14]. That meta-analysis assessed a total of 10 studies and reported discharge rates of $11.3 \%-51.7 \%$. The discharge level in our study was $81.5 \%$, similar to the levels reported in other studies from Turkey [15].

Two major limitations of our study are as follows: Our research is a retrospective study that only involves a period of four months. In addition, our study has been performed only at a single center.

Green zone patients are a significant component of emergency department overcrowding in Turkey. Various methods have been tried in order to reduce green zone cases in emergency departments. In addition to it being unethical for green zone patients to be transported by ambulance, these also contribute to emergency department crowding. We think that public awareness needs to be raised, and that educational activity directed toward in site patient assessment and triage will be beneficial.
In conclusion, In our country, triage applications consist of three steps(digits) that are determined by the colors. Although there are some studies on reliability and validity of triage implementation being used in Turkey, there is exist no multicenter studies regarding cost-benefit and evaluating the effect of patient density on triage applications. We believe that triage implementations should be reviewed in light of recent studies. Pre-hospital emergency health services need to be at the level of those in developed countries, and further research into interruptions to these services is needed.

\section{REFERENCES}

1. Farrohknia N, Castrén $M$, Ehrenberg $A$, et al. Emergency department triage scales and their components: A systematic review of the scientific evidence. Scand J Trauma Resusc Emerg Med 2011;19:1-13.

2. Erimşah ME, Yaka E, Yılmaz S, et al. Inter-rater reliability and validity of the Ministry of Health of Turkey's mandatory emergency triage instrument. Emerg Med Australas 2015;27:210-215.

3. Türkdoğan KA, Kapçı M, Akpınar A, et al. Demographic characteristics of patients a state hospital emergency service: meta-analysis of 2011. J Clin Exp Invest 2013;4:274-278.

4. Nur N, Demir ÖF, Çetinkaya S, et al. Evaluotion of the 112 emergency service use by older people. Turk J Geriatr 2008;11:7-11.

5. Keskinoglu P, Sofuoglu T, Ozmen O, et al. Older people's use of pre-hospital emergency medical services in Izmir, Turkey. Arch Gerontol Geriatr 2010;50:356-360.

6. Burt CW, McCaig LF, Valverde RH. Analysis of ambulance transports and diversions among US emergency departments. Ann Emerg Med 2006;47:317-326.

7. Marinovich A, Afilalo J, Afilalo M, et al. Impact of ambulance transportation on resource use in the emergency department. Acad Emerg Med 2004;11:312-15.

8. Kawakami C, Ohshige K, Kubota K, et al. Influence calls. BMC Health Serv Res 2007;7:120.

9. Seow E, Wong HP, Phe A. The pattern of ambulance arrivals in the emergency department of an acute care hospital in Singapore. Emerg Med J 2001;18:297-299.

10. Downing A, Wilson R. Older people's use of Accident and Emergency services. Age Ageing 2005;34:24-30.

11. Yıldız M, Durukan P. Analysis of patients transported to emergency department via ambulance. Turk J Emerg Med 2004;4:144-148.

12. Oktay $\mathrm{C}$, Çete $\mathrm{Y}$, Eray $\mathrm{O}$, et al. Are the laws sufficient enough to change the practice? Turk J Emerg Med. 2004;4:96-104.

13. Soysal S, Karcıoğlu Ö, Topaçoğlu H, ve ark. Ambulansla acil servise getirilen hastalara uygulanan hastane öncesi acil bakımın değerlendirilmesi. JAEM 2003;1:52-55.

14. Snooks $H$,Wringley $H$, George $S$, et al. Appropriateness of use of emergency ambulances. Accid Emerg Med 1998;15:212-218.

15. Çelik GK, Karakayalı O, Temrel TA, et al. Evaluation of patients transported to the emergency department by 112. Turk Med J 2012;6:73-76. 